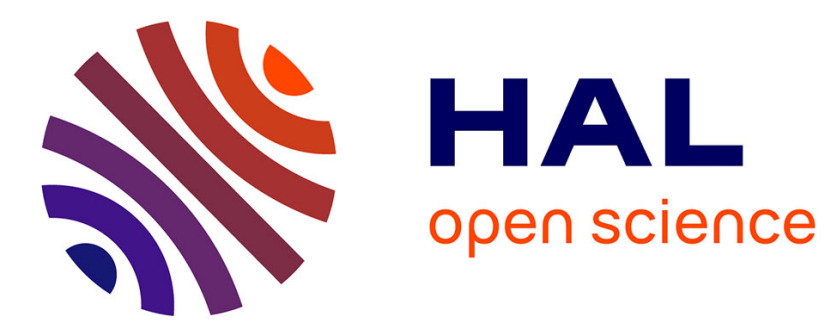

\title{
The effects of silica and water on the viscosity of hydrous quartzofeldspathic melts
}

Holtz François, Jacques Roux, S. Ohlhorst, Harald Behrens, F. Schulze

\section{To cite this version:}

Holtz François, Jacques Roux, S. Ohlhorst, Harald Behrens, F. Schulze. The effects of silica and water on the viscosity of hydrous quartzofeldspathic melts. American Mineralogist, 1999, 84, pp.27-36. hal-00077560

\section{HAL Id: hal-00077560 https://hal-insu.archives-ouvertes.fr/hal-00077560}

Submitted on 31 May 2006

HAL is a multi-disciplinary open access archive for the deposit and dissemination of scientific research documents, whether they are published or not. The documents may come from teaching and research institutions in France or abroad, or from public or private research centers.
L'archive ouverte pluridisciplinaire HAL, est destinée au dépôt et à la diffusion de documents scientifiques de niveau recherche, publiés ou non, émanant des établissements d'enseignement et de recherche français ou étrangers, des laboratoires publics ou privés. 


\title{
The effects of silica and water on the viscosity of hydrous quartzofeldspathic melts
}

\author{
F. Holtz, ${ }^{1, *}$ J. Roux, ${ }^{1}$ S. Ohlhorst, ${ }^{1,2}$ H. Behrens, ${ }^{2}$ And F. Schulze ${ }^{2}$ \\ ${ }^{1}$ CRSCM-CNRS, 1A rue de la férollerie, 45071 Orléans, France \\ ${ }^{2}$ Institut für Mineralogie, Universit;ät Hannover, Welfengarten 1, 30167 Hannover, Germany
}

\begin{abstract}
The viscosities of hydrous melts $\left(0.65\right.$ to $\left.2.8 \mathrm{wt} \% \mathrm{H}_{2} \mathrm{O}\right)$ with quartzofeldspathic compositions corresponding to $\mathrm{Ab}, \mathrm{Ab}_{74} \mathrm{Qz}_{26}$, and $\mathrm{Ab}_{48} \mathrm{Qz}_{52}$ (mole proportions calculated on the basis of eight oxygen atoms; $\mathrm{Ab}=\mathrm{NaAlSi}_{3} \mathrm{O}_{8}, \mathrm{Qz}=\mathrm{Si}_{4} \mathrm{O}_{8}$ ) have been determined between 980 and $1375{ }^{\circ} \mathrm{C}$ at pressures between 190 and $360 \mathrm{MPa}$ using the falling sphere technique. The use of large bubble-free hydrous glass cylinders (placed in internally heated pressure vessels) previously prepared and already containing markers and platinum spheres allows falling distances up to several centimeters to be measured with a precision of \pm 50 to 200 $\mu \mathrm{m}$. This results in a precision of $\pm 15 \%$ relative or less for most viscosity data $( \pm 10 \%$ relative or less if the temperature is known within $\pm 5^{\circ} \mathrm{C}$ ).

For a water content of $2.8 \mathrm{wt} \% \mathrm{H}_{2} \mathrm{O}$, viscosity increases with increasing Qz content. In the investigated viscosity range, no significant deviation from Arrhenian behavior is observed and the activation energy of viscous flow increases slightly with decreasing water content of the melt (for $\mathrm{Ab}$ ). Combining the experimental data obtained in this study with data for a haplogranitic composition investigated previously by Schulze et al. (1996) shows that the viscosities, and hence, the activation energies of viscous flow are similar for compositions with the same atom ratio $(\mathrm{Si}+\mathrm{Al}) /(\mathrm{H}+\mathrm{Na}+\mathrm{K})(\mathrm{SA} / \mathrm{HNK})$. Thus, melt viscosity is constant if $\mathrm{Al}$, charge balanced by $\mathrm{Na}$ or $\mathrm{K}$, is exchanged with $\mathrm{Si}+\mathrm{H}(\mathrm{H}$ incorporated as $\mathrm{OH}$ or $\mathrm{H}_{2} \mathrm{O}$ ). The viscosities (in $\mathrm{dPa} \cdot \mathrm{s}$ ) of all investigated hydrous haplogranite compositions with water contents ranging between 0.7 and $8.2 \mathrm{wt} \% \mathrm{H}_{2} \mathrm{O}$ can be calculated to better than $\pm 0.15 \log$ units using the expression:
\end{abstract}

$$
\log \eta=-1.8+\left[940+5598 \cdot(\mathrm{SA} / \mathrm{HNK})^{0.3774}\right] \cdot 1 / T
$$

where $T$ is expressed in Kelvin and varies from 1073 to $1650 \mathrm{~K}$.

\section{INTRODUCTION}

The high viscosities $\left(10^{10}\right.$ to $10^{14} \mathrm{~d} \cdot \mathrm{Pa} \cdot \mathrm{s}$ or poises $)$ of hydrous aluminosilicate glasses can be measured at 1 atm with different types of viscosimeters (e.g., Lejeune et al. 1994; Dingwell et al. 1996; Richet et al. 1996), if the temperature is low enough to avoid significant diffusion of water out of the sample (water is only dissolved at high pressure in aluminosilicate liquids with compositions close to those of natural melts). At high pressure $(P)$ and temperature $(T)$, determination of the viscosity of hydrous silicate liquids is notoriously difficult because experiments have to be carried out in sealed noble metal capsules, which makes in situ measurements difficult (for possible in situ techniques, see Kanzaki et al. 1987; Persikov et al. 1990). Until now, the most popular technique used for granitic melts is that of the falling sphere (e.g., Bacon 1935; Shaw 1963; Burnham 1964; Baker and Vaillancourt 1995; Scaillet et al. 1996). The precision of the viscosity determinations is mainly a function of the set-

\footnotetext{
* Current address: Institut für Mineralogie, Universität Hannover, Welfengarten 1, 30167 Hannover, Germany. E-mail: F.Holtz@mineralogie.uni-hannover.de
}

tling distance of the spheres (typically platinum spheres), of uncertainty in the position of platinum spheres before and after the experiments, and of the correction factors applied to account for the effects of viscous drag exerted on the settling spheres by the capsule walls (Faxen correction, see Shaw 1963). Most available data have been obtained from relatively small samples, yielding high uncertainties on the viscosity values, stated as $\pm 15 \%$ relative (e.g., Dingwell 1987; White and Montana 1990; Baker and Vaillancourt 1995). This uncertainty, together with possible systematic errors due to the application of different correction factors and with high uncertainties on the determination of the water contents in the melts, result in difficulties combining the available viscosity data sets, which are not always consistent. For example, the data in Figure 1 suggest that almost identical viscosities are obtained for albite melts containing 2.8 and $4.5 \mathrm{wt} \mathrm{H}_{2} \mathrm{O}$ and that melts containing $5.6 \mathrm{wt} \% \mathrm{H}_{2} \mathrm{O}$ are slightly less viscous than melts containing $6.9 \mathrm{wt} \% \mathrm{H}_{2} \mathrm{O}$ (data from Dingwell 1987 and Persikov et al. 1990, respectively), which is not realistic because melt viscosity is known to decrease with increasing water content. Thus, although the 


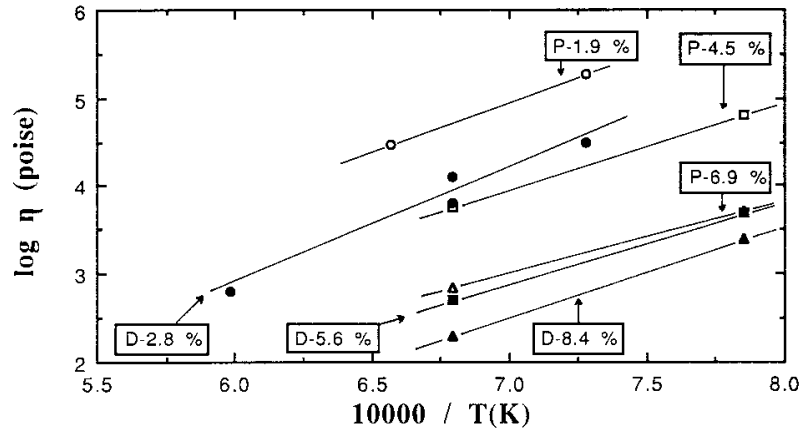

Figure 1. Experimentally determined viscosities (symbols) for hydrous albite melts from previous studies. Open symbols are data obtained by Persikov et al. (1990) at 50, 100, and $200 \mathrm{MPa}$ for melt water contents of $1.9,4.5$, and $6.9 \mathrm{wt} \% \mathrm{H}_{2} \mathrm{O}$, respectively. Filled symbols are data obtained by Dingwell (1987) at $250 \mathrm{MPa}$ (two points for $2.8 \mathrm{wt} \% \mathrm{H}_{2} \mathrm{O}$ ) and $750 \mathrm{MPa}$ (all other data). Note the discrepancies between the different data sets: For example, the viscosity of a melt with $6.9 \mathrm{wt} \% \mathrm{H}_{2} \mathrm{O}$ (data from Persikov et al. 1990) is higher than that of a melt with $5.6 \mathrm{wt} \%$ $\mathrm{H}_{2} \mathrm{O}$ (data from Dingwell 1987).

available data for albite melts (Dingwell 1987; Persikov et al. 1990; Baker 1996) allow the general effect of water on the viscosity to be determined (probably within one $\log$ unit), the effects of small compositional variations (anhydrous composition or water content) cannot be constrained. This makes it difficult to model melt viscosities accurately and to interpret the structural effect of water on aluminosilicate liquids, which is required to understand the evolution of the rheological and chemical properties of magmas during crystallization, degassing, transport, and eruption processes.

In this study, the falling sphere technique has been improved (see also Schulze et al. 1996) to determine the effects of water and anhydrous composition on the viscosity of haplogranitic hydrous melts. The viscosity of melts with compositions along the $\mathrm{NaAlSi}_{3} \mathrm{O}_{8}-\mathrm{Si}_{4} \mathrm{O}_{8}(\mathrm{Ab}-$ Qz) join is investigated. This study complements that of Schulze et al. (1996), who determined the effect of water on one haplogranitic composition $\left(\mathrm{Ab}_{38} \mathrm{Or}_{34} \mathrm{Qz}_{28}\right.$, mole proportions on the basis of eight oxygen atoms, Or = $\mathrm{KAlSi}_{3} \mathrm{O}_{8}$ ). The experimental results permit prediction of the viscosity of haplogranite melts with a precision better than $\pm 0.15 \log$ units, provide new constraints on the structure of hydrous aluminosilicate liquids, and have implications for estimating viscosities of natural granitic melts.

\section{Starting MATERIALS AND METHOD}

The technique employed in this study to determine the viscosity of hydrous melts is very similar to that used by Shaw (1963), and requires three preliminary experimental steps before viscosity experiments are carried out (see also Schulze et al. 1996).
TABLE 1. Average compositions of hydrous starting glasses used for the viscosity determinations

\begin{tabular}{lcccc}
\hline \hline Sample & $\begin{array}{c}\mathrm{Ab} \\
0.65 \% \mathrm{H}_{2} \mathrm{O}\end{array}$ & $\begin{array}{c}\mathrm{Ab} \\
3 \% \mathrm{H}_{2} \mathrm{O}\end{array}$ & $\begin{array}{c}\mathrm{Ab}_{75} \mathrm{Qz}_{25} \\
3 \% \mathrm{H}_{2} \mathrm{O}\end{array}$ & $\begin{array}{c}\mathrm{Ab}_{50} \mathrm{Qz}_{50} \\
3 \% \mathrm{H}_{2} \mathrm{O}\end{array}$ \\
$\begin{array}{c}\text { Number of } \\
\text { analyses }\end{array}$ & 7 & 9 & 9 & 8 \\
\hline $\mathrm{SiO}_{2}$ & $69.00(0.63)$ & $66.57(0.50)$ & $75.89(0.92)$ & $80.67(0.53)$ \\
$\mathrm{Al}_{2} \mathrm{O}_{3}$ & $19.80(0.34)$ & $18.86(0.26)$ & $13.35(0.33)$ & $10.11(0.12)$ \\
$\mathrm{Na}_{2} \mathrm{O}$ & $11.82(0.09)$ & $11.46(0.19)$ & $7.80(0.25)$ & $5.75(0.19)$ \\
$\mathrm{Total}^{4}$ & 100.62 & 96.83 & 97.04 & 96.53 \\
\multicolumn{5}{c}{$\mathrm{CIPW}$} \\
$\mathrm{Qz}$ & 0.30 & 0.28 & 31.43 & 48.90 \\
$\mathrm{Ab}$ & 99.34 & 99.58 & 68.03 & 50.43 \\
corundum & 0.36 & 0.04 & 0.54 & 0.67 \\
SA/HNK & 3.37 & 2.15 & 2.68 & 3.11
\end{tabular}

Note: Analyses are averages of all analyzed spots, with standard deviations given in parentheses. A correction factor of 1.06 was applied for $\mathrm{Na}$ based on the analysis of standard samples having microprobe in the BRGM-CNRS analytical laboratory at Orléans. Procedures for analysis of glasses are described in Scaillet et al. (1995).

${ }^{*} \mathrm{SA} / \mathrm{HNK}=(\mathrm{Si}+\mathrm{Al}) /(\mathrm{H}+\mathrm{Na}+\mathrm{K})$ molar. $\mathrm{H}$ is determined from the average $\mathrm{H}_{2} \mathrm{O}$ contents given in Table 2 .

Synthesis and composition of anhydrous glasses (step 1)

Three starting compositions have been investigated along the $\mathrm{Qz}-\mathrm{Ab}$ join. Two dry glasses, $\mathrm{Ab}_{75} \mathrm{Qz}_{25}$ and $\mathrm{Ab}_{50} \mathrm{Qz}_{50}$ (proportions expressed in weight percent of $\mathrm{NaAlSi}_{3} \mathrm{O}_{8}$ and $\mathrm{SiO}_{2}$ ), were prepared by heating up a mixture of oxides $\left(\mathrm{SiO}_{2}, \mathrm{Al}_{2} \mathrm{O}_{3}\right)$ and carbonates $\left(\mathrm{Na}_{2} \mathrm{CO}_{3}\right)$ at $1600{ }^{\circ} \mathrm{C}$ and $1 \mathrm{~atm}$ for 4 to $5 \mathrm{~h}$. After cooling, the glasses contained numerous gas bubbles. The compositions of these glasses are $A b_{74} \mathrm{Qz}_{26}$ and $\mathrm{Ab}_{48} \mathrm{Qz}_{52}$ with $\mathrm{Ab}=$ $\mathrm{NaAlSi}_{3} \mathrm{O}_{8}$ and $\mathrm{Qz}=\mathrm{Si}_{4} \mathrm{O}_{8}$. The dry $\mathrm{Ab}$ glass was synthesized by Schott company (no. 8887, composition AbI in Behrens 1995) and contained only a few gas bubbles. Analysis of several pieces of each composition indicate chemical homogeneity (Table 1).

\section{Preparation of hydrous glass samples (step 2)}

The water-bearing glasses were synthesized in an internally heated pressure vessel (IHPV) at high $P$ and $T$ in sealed platinum capsules (40 $\mathrm{mm}$ long, $5 \mathrm{~mm}$ inner diameter) containing the anhydrous glass powder (obtained by grinding the glasses synthesized in step 1 experiments) and the desired amount of distilled water (0.5 and $3 \mathrm{wt} \%$ $\mathrm{H}_{2} \mathrm{O}$ added). The sealed capsules were heated at $120{ }^{\circ} \mathrm{C}$ for 1 to $10 \mathrm{~h}$ to check for leaks and to homogenize water in the glass powder. The applied $P-T$ conditions were 200 to $500 \mathrm{MPa}$ and 1300 to $1375^{\circ} \mathrm{C}$. Experiments were conducted for 65 to 80 hours. The shapes of the resultant glass blocks were roughly cylindrical. The glasses with 3 wt $\%$ added $\mathrm{H}_{2} \mathrm{O}$ were bubble-free. A few bubbles (up to $20 \mu \mathrm{m}$ ) were present in the Ab glass with $0.5 \mathrm{wt} \%$ added $\mathrm{H}_{2} \mathrm{O}$. The synthesis was performed at $200 \mathrm{MPa}$ and this pressure was probably not sufficient to remove all air bubbles (no water could be detected in the bubbles with Raman spectroscopy). Both ends of the cylinders were cut to check anhydrous composition (Table 1) and determine whether water was distributed homogeneously in the glass (Table 2). The central parts were used to prepare 
TABLE 2. Water content of starting hydrous glasses used for the viscosity determinations and water contents of glasses after the viscosity determinations

\begin{tabular}{ccccc}
\hline \hline Sample & $\begin{array}{c}\mathrm{Ab} \\
0.65 \% \mathrm{H}_{2} \mathrm{O}\end{array}$ & $\begin{array}{c}\mathrm{Ab} \\
2.8 \% \mathrm{H}_{2} \mathrm{O}\end{array}$ & $\begin{array}{c}\mathrm{Ab}_{75} \mathrm{Qz}_{25} \\
2.8 \% \mathrm{H}_{2} \mathrm{O}\end{array}$ & $\begin{array}{c}\mathrm{Ab}_{50} \mathrm{Qz}_{50} \\
2.8 \% \mathrm{H}_{2} \mathrm{O}\end{array}$ \\
\hline $\begin{array}{c}\text { step 2 experiments } \\
\text { end } \mathrm{A} \text { of cylinder }\end{array}$ & 0.65 & 3.06 & 3.55 & 2.82 \\
$\begin{array}{c}\text { step 2 experiments } \\
\text { end } \mathrm{B} \text { of cylinder }\end{array}$ & 0.62 & 2.61 & 2.53 & 2.82 \\
$\begin{array}{c}\text { after step 4 experiments } \\
\text { end } \mathrm{A} \text { of cylinder }\end{array}$ & 0.65 & 2.83 & 2.72 & 2.72 \\
$\begin{array}{c}\text { after step 4 experiments } \\
\text { end } \mathrm{B} \text { of cylinder }\end{array}$ & $\mathrm{ND}$ & 2.87 & 2.92 & 2.81 \\
$\begin{array}{c}\text { average } \mathrm{H}_{2} \mathrm{O} \text { content } \\
\text { of the meltt }\end{array}$ & 0.65 & 2.85 & 2.82 & 2.77 \\
\hline
\end{tabular}

Note: All analyses were performed by Karl Fischer titration (see precision in text). Ends A and B refer to the two ends of the cylinders. The analyses were performed from glass pieces collected after the hydration experiments (step 2 experiments, see text) and after the viscosity experiment (after step 4 experiments). ND = not determined.

* The average $\mathrm{H}_{2} \mathrm{O}$ content is calculated from the determinations made after the experiments.

hydrous glass cylinders with a perfect cylindrical shape and a diameter of $4 \mathrm{~mm}$. One sample is slightly more Qzrich than expected $\left(\mathrm{Ab}_{75} \mathrm{Qz}_{25}\right.$, Table 1$)$, and two are slightly peraluminous $\left(\mathrm{Ab}_{75} \mathrm{Qz}_{25}\right.$ and $\mathrm{Ab}_{50} \mathrm{Qz}_{50}$, Table 1$)$.

\section{Sample preparation for viscosity determinations (step 3)}

The glass cylinders with a diameter of $4 \mathrm{~mm}$ (15 to 18 $\mathrm{mm}$ long) were loaded into platinum capsules along with one or two platinum spheres and a platinum marker. Platinum powder was placed at the bottom of the capsule between a slice of glass and the cylinder to obtain a marker perpendicular to the long axis of the cylinder. The platinum sphere(s), surrounded by glass powder (collected from the second step experiments), were placed at the top of the capsule. Both the diameter and weight of the platinum spheres were determined before they were loaded into the capsule. Only spheres that yielded the same diameter from both direct microscopic determination and weighing were used. The capsule was sealed and then placed in an IHPV at the same $P-T$ conditions as those planned for the viscosity determinations. Run times ranged from 30 to $60 \mathrm{~min}$. After the experiment, most of the spheres were still spherical. However, some became slightly ellipsoidal or lenticular, probably due to pressure exerted at room temperature by the glass fragments on the spheres (pressure is applied before heating up in the experimental procedure). The positions of the platinum marker and of the spheres within the translucent glass sample were determined using a microscope equipped with an automated $x-y$ stage. Several determinations of a distance (up to $10 \mathrm{~mm}$ ) between two points showed a variation of less than $5 \mu \mathrm{m}$.

\section{Determination of viscosity (step 4)}

Viscosity experiments were performed by sealing the glass cylinder (obtained from step 3 ) in a platinum capsule, holding it at the desired $P$ and $T$, and determining the settling distance(s) of the sphere(s) after the quench. The latter was measured with a microscope (see above) using the position of the marker, considered to be static, and that of the spheres before and after the experiments (Table 3). Several runs were performed at different $P-T$ conditions with the same glass cylinder, thus allowing determination of melt viscosities using the same sample at different conditions. After each experiment, the platinum capsule was opened, the falling distance was measured, the glass cylinder was turned upside down (so that the platinum spheres were falling back in the opposite direction from the previous experiment), and sealed again in a new platinum capsule for the next experiment.

The viscosity, $\eta$ (in $\mathrm{dPa} \cdot \mathrm{s}$ or poises), is derived from the equation

$$
\eta=2 \cdot g \cdot \Delta \rho \cdot r^{2} \cdot \mathrm{C}_{\mathrm{f}} / 9 \cdot v
$$

where $r$ is the radius $(\mathrm{cm})$ of the sphere, $g$ the acceleration due to gravity $\left(\mathrm{cm} / \mathrm{s}^{2}\right), \Delta \rho$ the density $\left(\mathrm{g} / \mathrm{cm}^{3}\right)$ difference between that of the platinum sphere (21.45) and of the melt, $\mathrm{C}_{\mathrm{f}}$ the Faxen correction, and $v$ the settling velocity of the spheres $(\mathrm{cm} / \mathrm{s})$. The mathematical expression for $\mathrm{C}_{\mathrm{f}}$ is given by Shaw (1963, Eq. 2), Dingwell (1987, Eq. 3), and Schulze et al. (1996, Eq. 2). The values of $C_{f}$ and of the density of the melt used to calculate the viscosities are given in Table 3. The Faxen correction used in Equation 1 takes the effects of capsule walls into account (noninfinite medium), but not the possible effects of the ends of the capsule (see discussion). The density values that have been used were taken from studies of Behrens et al. (1996) for Ab glasses, and extrapolated from the studies of Schulze et al. (1996) and Behrens et al. (1996) for the $\mathrm{Ab}-\mathrm{Qz}$ glasses. The small variations of the density due to this extrapolation as well as those resulting from the extrapolation of the density of glasses to that of melts do not affect significantly the viscosity determination (Dingwell and Mysen 1985; Schulze et al. 1996). In one sample $\left(\mathrm{Ab}_{50} \mathrm{Qz}_{50}\right)$, one platinum sphere was extremely deformed after the preparation experiment [lenticular shape with an axial ratio (c/a) of $\sim 0.6]$. On the basis of results of Kerr and Lister (1991), a correction factor of $0.9\left(\eta_{\text {melt }}=0.9\right.$ $\eta_{\text {determined }}$ ) was applied to determine melt viscosity (Table 3).

In glass cylinders containing two spheres, two independent viscosity determinations are obtained for each experiment using Equation 1. A third viscosity value can be calculated using the difference of the settling distances of the two spheres. The latter determination does not require the existence of a marker and is given by the equation:

$$
\eta=2 \cdot g \cdot \Delta \rho \cdot t \cdot\left(r_{\mathrm{f}}^{2} \cdot \mathrm{C}_{\mathrm{fl}}-r_{2}^{2} \cdot \mathrm{C}_{\mathrm{f} 2}\right) / 9 \cdot \Delta d
$$

where $t$ is the experimental duration (in seconds) and $\Delta d$ the difference of settling distances $\left(d_{1}-d_{2}\right.$ in $\left.\mathrm{cm}\right)$ between spheres 1 and $2\left(r_{1}, \mathrm{C}_{\mathrm{f} 1}, r_{2}, \mathrm{C}_{\mathrm{f} 2}\right.$, are the radii and Faxen corrections for spheres 1 and 2 , respectively). 
TABLE 3. Experimental conditions and results of viscosity determinations in Qz-Ab hydrous melts

\begin{tabular}{|c|c|c|c|c|c|c|c|}
\hline $\mathrm{T}\left({ }^{\circ} \mathrm{C}\right)$ & $P(\mathrm{MPa})$ & $\begin{array}{l}\text { Experimental } \\
\text { duration(s) }\end{array}$ & $\begin{array}{l}\text { Sphere* } \\
\text { radius }(\mu \mathrm{m})\end{array}$ & $\begin{array}{c}\text { Settling } \\
\text { distance }(\mathrm{mm})\end{array}$ & $\begin{array}{c}\log _{\eta}(\exp ) \\
(\mathrm{dPa} \cdot \mathrm{s})\end{array}$ & 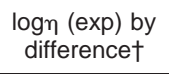 & $\begin{array}{c}\log _{(\mathrm{dPa}} \text { (calc) } \\
\text { (c) }\end{array}$ \\
\hline \multicolumn{8}{|c|}{$\mathrm{Ab}-0.65 \mathrm{wt} \% \mathrm{H}_{2} \mathrm{O}\left(\mathrm{C}_{\mathrm{f}}=0.869\right.$ for $r=125 \mu \mathrm{m} ; \mathrm{C}_{\mathrm{f}}=0.861$ for $\left.r=133 \mu \mathrm{m} ; d=2.36\right)$} \\
\hline 1275 & 360 & 33185 & $\begin{array}{l}125 \\
133\end{array}$ & $\begin{array}{l}4.267 \pm 0.12 \\
4.436 \pm 0.12\end{array}$ & $\begin{array}{l}4.64 \\
4.67\end{array}$ & 5.10 & 4.53 \\
\hline 1325 & 360 & 6480 & $\begin{array}{l}125 \\
133\end{array}$ & $\begin{array}{l}1.271 \pm 0.12 \\
1.411 \pm 0.08\end{array}$ & $\begin{array}{l}4.46 \\
4.46\end{array}$ & 4.47 & 4.33 \\
\hline 1375 & 340 & 10620 & $\begin{array}{l}125 \\
133\end{array}$ & $\begin{array}{l}3.596 \pm 0.15 \\
3.975 \pm 0.09\end{array}$ & $\begin{array}{l}4.22 \\
4.23\end{array}$ & 4.25 & 4.14 \\
\hline \multicolumn{8}{|c|}{$\mathrm{Ab}-2.8 \mathrm{wt} \% \mathrm{H}_{2} \mathrm{O}\left(\mathrm{C}_{\mathrm{f}}=0.874\right.$ for $\left.r=120 \mu \mathrm{m} ; d=2.33\right)$} \\
\hline $\begin{array}{r}980 \\
1140 \\
1200\end{array}$ & $\begin{array}{l}320 \\
310 \\
310\end{array}$ & $\begin{array}{l}25170 \\
23480 \\
19980\end{array}$ & $\begin{array}{l}120 \\
120 \\
120\end{array}$ & $\begin{array}{r}1.30 \pm 0.08 \\
7.47 \pm 0.30 \\
10.65 \pm 0.30\end{array}$ & $\begin{array}{l}5.01 \\
4.22 \\
3.99\end{array}$ & & $\begin{array}{l}4.91 \\
4.15 \\
3.91\end{array}$ \\
\hline \multicolumn{8}{|c|}{$\mathrm{Ab}_{75} \mathrm{Qz}_{25}-2.8 \mathrm{wt} \% \mathrm{H}_{2} \mathrm{O}\left(\mathrm{C}_{\mathrm{f}}=0.890\right.$ for $r=105 \mu \mathrm{m} ; \mathrm{Cf}=0.872$ for $\left.r=126 \mu \mathrm{m} ; d=2.34\right)$} \\
\hline 1115 & 280 & 42391 & $\begin{array}{l}105 \\
126\end{array}$ & $\begin{array}{l}319 \pm 0.08 \\
4.72 \pm 0.17\end{array}$ & $\begin{array}{l}4.74 \\
4.72\end{array}$ & 4.66 & 4.73 \\
\hline 1200 & 290 & 19320 & $\begin{array}{l}105 \\
126\end{array}$ & $\begin{array}{l}4.07 \pm 0.15 \\
5.79 \pm 0.15\end{array}$ & $\begin{array}{l}4.29 \\
4.29\end{array}$ & 4.27 & 4.35 \\
\hline 1307 & 290 & 4050 & $\begin{array}{l}105 \\
126\end{array}$ & $\begin{array}{l}2.42 \pm 0.09 \\
3.38 \pm 0.25\end{array}$ & $\begin{array}{l}3.84 \\
3.84\end{array}$ & 3.85 & 3.93 \\
\hline 1307 & 280 & 7140 & $\begin{array}{l}105 \\
126\end{array}$ & $\begin{array}{l}4.15 \pm 0.12 \\
5.80 \pm 0.20\end{array}$ & $\begin{array}{l}3.84 \\
3.85\end{array}$ & 3.86 & 3.93 \\
\hline \multicolumn{8}{|c|}{$\mathrm{Ab}_{50} \mathrm{Qz} \mathrm{z}_{50}-2.8 \mathrm{wt} \% \mathrm{H}_{2} \mathrm{O}\left(\mathrm{C}_{\mathrm{f}}=0.857\right.$ for $r=136.5 \mu \mathrm{m} ; \mathrm{Cf}=0.834$ for $\left.r=159 \mu \mathrm{m} ; d=2.30\right)$} \\
\hline 1135 & 210 & 65795 & $\begin{array}{l}136.5^{*} \\
159\end{array}$ & $\begin{array}{l}4.50 \pm 0.08 \\
6.84 \pm 0.08\end{array}$ & $\begin{array}{l}4.94^{*} \\
4.93\end{array}$ & $(4.77) \dagger$ & 4.97 \\
\hline 1200 & 190 & 25980 & $\begin{array}{l}136.5^{\star} \\
159\end{array}$ & $\begin{array}{l}3.55 \pm 0.05 \\
5.15 \pm 0.05\end{array}$ & $\begin{array}{l}4.64^{*} \\
4.65\end{array}$ & $(4.54) \dagger$ & 4.70 \\
\hline 1305 & 190 & 10650 & $\begin{array}{l}136.5^{\star} \\
159\end{array}$ & $\begin{array}{l}4.06 \pm 0.05 \\
6.17 \pm 0.05\end{array}$ & $\begin{array}{l}4.20^{*} \\
4.18\end{array}$ & $(4.03) \dagger$ & 4.24 \\
\hline
\end{tabular}

Note: $\mathrm{C}_{\mathrm{f}}, r$, and $d$ are the Faxen correction, sphere radius, and density, respectively, used for the determination of viscosities [log $\eta($ exp)]. The viscosity calculated from Equation 4 is given for comparison [ $\log \eta($ calc)].

* The radii of the spheres indicated in the table are those determined before the experiments. The value of the experimentally determined viscosity has been corrected by a factor of 0.9 to account for the lenticular shape of the sphere with an initial radius of 136.5 in composition $A b_{50} Q z_{50}$ (see text).

$\dagger$ Viscosity values calculated from the settling difference of the two spheres, using Equation 2 (see text). This calculation does not take into account the shape of the spheres; if one or both spheres is not strictly spherical, the viscosity value is erroneous.

\section{EXPERIMENTAL AND ANALYTICAL TECHNIQUES} Experimental apparatus

All experiments at high $P-T$ conditions were conducted in two IHPV, equipped with high-temperature furnaces allowing temperatures up to $1400{ }^{\circ} \mathrm{C}$ to be reached with temperature gradients of less than $10-15$ ${ }^{\circ} \mathrm{C}$ along 30-40 mm long capsules (three PtRh6PtRh30 thermocouples were positioned along the capsules). A detailed description of the pressure vessels and furnaces is given by Roux and Lefèvre (1992) and Roux et al. (1994). The experimental conditions for the experiments designed to measure melt viscosities (980-1375 $\left.{ }^{\circ} \mathrm{C}, 190-360 \mathrm{MPa}\right)$ and durations $(67-1096$ min) are listed in Table 3 . The heating rate between $800{ }^{\circ} \mathrm{C}$ and the desired temperature varied between 120 and $160{ }^{\circ} \mathrm{C} / \mathrm{min}$. The cooling rate between 1375 and $900{ }^{\circ} \mathrm{C}$ was approximately $120{ }^{\circ} \mathrm{C} / \mathrm{min}$.

\section{Water content of glasses}

The water contents of the glasses were determined by Karl Fischer titration (KFT). This technique, also used for the determination of water solubilities, is described in detail by Behrens (1995) and Holtz et al. (1995). The relative precision depends mainly on the duration of ti- tration and on the amount of water that is titrated. In this study, the water content was determined with an absolute precision of $\pm 0.15 \mathrm{wt} \% \mathrm{H}_{2} \mathrm{O}$.

The water contents at both ends of the hydrous glasses synthesized in the second experimental step were almost identical for three samples, but one sample was not perfectly homogeneous $\left(\mathrm{Ab}_{75} \mathrm{Qz}_{25}\right.$, Table 2$)$, which is probably the result of a heterogeneous distribution of water within the glass powder before the synthesis of the hydrous glasses. To reduce the water gradient along the sample, this glass was subsequently heated at $1250{ }^{\circ} \mathrm{C}$ and $300 \mathrm{MPa}$ for $4 \mathrm{~h}$ before the viscosity determination experiments. The identical viscosities obtained for two experiments at $1307{ }^{\circ} \mathrm{C}$ (Table 3), which corresponds to the first and last viscosity experiments conducted with sample $A b_{75} \mathrm{Qz}_{25}$ is evidence for a homogeneous distribution of water in the melt during the viscosity experiments. In addition, water contents at both ends of this glass sample analyzed after the last viscosity experiment are identical within error (Table 2). For the other samples, no loss of water occurred during the experiments and water contents determined before (after step 2 experiments) and after the viscosity determinations (Table 2) were identical. 

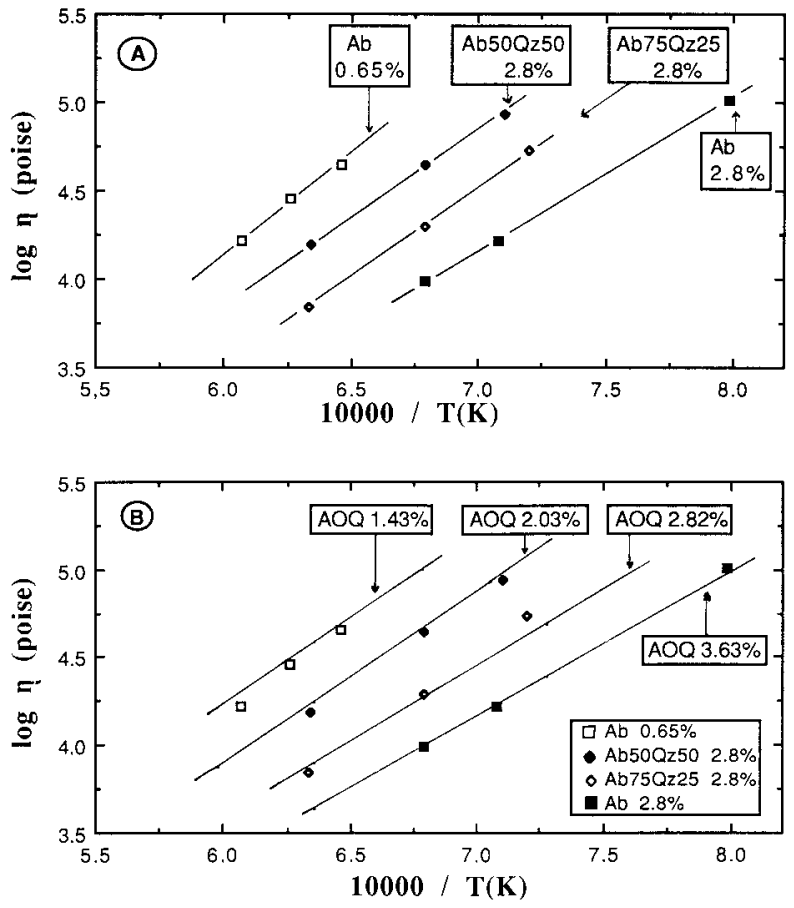

Figure 2. Viscosities of hydrous Ab-Qz (normative proportions indicated in the figure) and AOQ melts $\left(\mathrm{Ab}_{38} \mathrm{Or}_{34} \mathrm{Qz}_{28}\right.$, normative proportions) as a function of the reciprocal absolute temperature. Symbols in Figure 2A and 2B are the experimental data obtained for Ab-Qz melts (Table 3). Lines in Figure 2A are fitted through the experimental data for each composition. Lines in Figure $2 \mathrm{~B}$ represent the viscosities calculated for AOQ melts, using the equation given by Schulze et al. (1996) for the indicated water content. Note that the experimentally determined viscosities for $\mathrm{Ab}_{50} \mathrm{Qz}_{50}+2.8 \mathrm{wt} \% \mathrm{H}_{2} \mathrm{O}$ and $\mathrm{Ab}+2.8 \mathrm{wt} \% \mathrm{H}_{2} \mathrm{O}$ are very close to the viscosities for AOQ melts +2.03 and 3.63 wt $\% \mathrm{H}_{2} \mathrm{O}$, respectively.

\section{EXPERIMENTAL RESULTS}

The measured settling velocities of the platinum spheres and the resulting viscosity data are listed in Table 3 . The size of the platinum spheres (determined before the experiments), the applied Faxen corrections, and the density of the melts that have been used to calculate viscosity are also given in Table 3. An additional correction was applied to account for the lenticular shape of one platinum sphere (sample $\mathrm{Ab}_{50} \mathrm{Qz}_{50}$, see above and Table $3)$. When two platinum spheres were incorporated in the samples, the maximum viscosity variation calculated from the settling distance between the marker and each sphere is $0.03 \log$ units [ $\log \eta(\exp )$ in Table 3]. For two compositions ( $\mathrm{Ab}-0.65 \% \mathrm{H}_{2} \mathrm{O}$ and $\mathrm{Ab}_{75} \mathrm{Qz}_{25}-2.8 \% \mathrm{H}_{2} \mathrm{O}$ ), the viscosities calculated from the difference of the settling distances of the two spheres (Eq. 2) are also in good agreement with those determined using the platinum marker, except for one experiment (Ab- $0.65 \% \mathrm{H}_{2} \mathrm{O}, 1275$ ${ }^{\circ} \mathrm{C}$, Table 3). This difference is due either to an error in the measurement of the falling distances or to a delayed start of one of the spheres at the beginning of the experiment. Because of the long settling distance, the viscosities determined using the marker are almost identical for this experiment and can be considered as valid. For composition $\mathrm{Ab}_{50} \mathrm{Qz}_{50}$, the viscosities calculated from the difference of settling distances yield erroneous values because of the lenticular shape of one of the spheres. This shows that the comparison of viscosities calculated using Equations 1 and 2 is a good test for possible experimental problems (e.g., mistakes in the distance measurements). In this paper, viscosities reported in figures and used for calculations are average values of viscosities obtained from Equation 1.

At a given temperature, melt viscosity increases with increasing Qz content (samples with 2.8 wt $\% \mathrm{H}_{2} \mathrm{O}$ ) and with decreasing water content (Ab melt). For all compositions, the viscosity has an Arrhenian behavior in the investigated temperature range (Fig. 2A) and can therefore be represented by the equation

$$
\left.\log \eta=\log \eta_{\mathrm{o}}+E_{a} / 2.303 \cdot R \cdot T\right)
$$

where $\log \eta_{\mathrm{o}}$ is the pre-exponential factor, $E_{a}$ the activation energy of viscous flow $(\mathrm{kJ} / \mathrm{mol}), R$ the gas constant, and $T$ the temperature (kelvin). The values for $\log \eta_{\mathrm{o}}$ and $E_{a}$ are given in Table 4 and were calculated using linear regressions.

\section{Discussion}

\section{Precision of the viscosity data compared to previous studies}

The use of long glass cylinders in which platinum spheres and markers are incorporated in preliminary experiments (step 3), of platinum spheres with small radii, and of long experimental durations improve the quality of the viscosity data. The precision of our data is probably better than that obtained by Shaw (1963), because no platinum marker was used in that pioneering study (distances were measured using the end of the glass cylinders as a reference). In addition, the samples used by Shaw (1963) were shorter (maximum $10 \mathrm{~mm}$ long glass cylinders), the radius of the platinum spheres larger $(r=250$

TABLE 4. Activation energies of viscous flow and pre-exponential coefficients determined from the experimental results

\begin{tabular}{lcccc}
\hline \hline & $\mathrm{Ab}$ & $\mathrm{Ab}$ & $\mathrm{Ab}_{50} \mathrm{Qz}_{50}$ & \\
\multicolumn{1}{c}{ Sample } & $0.65 \% \mathrm{H}_{2} \mathrm{O}$ & $2.8 \% \mathrm{H}_{2} \mathrm{O}$ & $2.8 \% \mathrm{~Hz}_{25} \mathrm{O}$ & $2.8 \% \mathrm{H}_{2} \mathrm{O}$ \\
\hline activation energy, $E_{a}(\mathrm{~kJ} / \mathrm{mol})$ & $210( \pm 43)$ & $165( \pm 13)$ & $193( \pm 19)$ & $187( \pm 22)$ \\
$\log \eta_{\mathrm{o}}(\mathrm{dPa} \cdot \mathrm{s})$ & $-2.41( \pm 1.39)$ & $-1.86( \pm 0.49)$ & $-2.55( \pm 0.68)$ & $-1.99( \pm 0.76)$ \\
\hline Note: The error given in parentheses has been calculated considering that the viscosity is determined with a precision of $\pm 10 \%$ relative. \\
\hline
\end{tabular}


to $400 \mu \mathrm{m}$ ), and the radius of the glass cylinders smaller $(R=0.125 \mathrm{~cm})$, resulting in Faxen correction values that were higher (thus increasing potential error in viscosity determinations). In the present study, the correction for the height of the cylinder (end effects of the capsule) would result in a maximum variation of $0.015 \mathrm{log}$ units for the viscosity and can be neglected (see calculation in Shaw 1963).

The major source of error in experiments based on the falling sphere technique is generally considered to be the precision of the settling distance of the spheres (e.g., Shaw 1963). In this study, the positions of the sphere and of the marker were determined without changing the focus of the microscope. The distance between the sphere and marker was measured six to ten times for three or more positions of the cylinder (obtained by rotation of the cylinder), and an average settling distance of each sphere is given in Table 3. The maximum and minimum values were used to calculate the error of the settling distance given in Table 3 . In the case of long settling distances and for small variations (e.g., the experiment with $\mathrm{Ab}_{50} \mathrm{Qz}_{50}$ at $1135^{\circ} \mathrm{C}$, sphere with $\left.r=159 \mu \mathrm{m}\right)$, the precision of the viscosity can be as good as $\pm 0.0035 \log$ units or $\pm 0.8 \%$ relative. For all other determinations, the error of the viscosity due to the measurement of the settling distance of at least one platinum sphere is $< \pm 6 \%$ relative (corresponding to $\pm 0.025-0.03 \log$ units), except for $\mathrm{Ab}-0.65 \mathrm{wt} \% \mathrm{H}_{2} \mathrm{O}$ at $1325{ }^{\circ} \mathrm{C}$ with an error of $\pm 10 \%$ relative $( \pm 0.05 \log$ units). The uncertainties for most viscosities are within $\pm 1-4 \%$ relative. In samples containing two platinum spheres, the viscosity determinations could be duplicated, and the variation resulting from the determination of the settling distance of each sphere is $7.1 \%$ relative for one experiment and $<5 \%$ relative for all other experiments.

The uncertainty in measuring the time of descent varies with the duration of the experiment. To calculate the velocity of the sphere, the beginning of the experiment was considered to be $10{ }^{\circ} \mathrm{C}$ under the set point. The end of the experiment was the moment at which power was turned off. If a correction of $2 \mathrm{~min}$ is applied, which takes into account the heating and cooling time between the set point and a temperature $120{ }^{\circ} \mathrm{C}$ below the set point. It also takes into account the viscosity increases by $2 \%$ relative for experiments with durations of 6000 to $10000 \mathrm{~s}$ $(+0.01 \log$ units or less) and by $1 \%$ relative or less for experiments with durations longer than $19000 \mathrm{~s}$. The uncertainty is $2.8 \%$ relative for the shortest experiment (4050 s).

The possible lag in the starting time of sinking of the platinum sphere can be determined with experiments of different durations. The effect of experimental duration was tested for one condition $\left(1307{ }^{\circ} \mathrm{C}\right.$ for composition $\left.A b_{75} Q_{25}\right)$ and the viscosities were found to be identical after 4050 and $7140 \mathrm{~s}$ (Table 3). This was also observed by Schulze et al. (1996) for $\mathrm{Ab}_{38} \mathrm{Or}_{34} \mathrm{Qz}_{28}$ (AOQ) melts. Because of the long experimental durations (always $>4000 \mathrm{~s}$ ), it was not deemed necessary to test systemat- ically that identical viscosities are obtained as a function of time.

The technique employed in this study significantly minimizes the uncertainties resulting from measurement of settling distances, and the determination of temperature becomes the most important source of error. The temperature is known with a precision better than $\pm 10^{\circ} \mathrm{C}$. This range takes into account both the temperature gradient along the sample and the precision of thermocouples. The resulting effects on viscosity range between $\pm 8-11 \%$ relative, depending on the temperature $( \pm 0.04-0.05 \mathrm{log}$ units). Because all viscosity (step 4) experiments were performed in the same IHPV, and because the maximum temperature was always recorded in the central part of the sample where the platinum spheres were located, temperature readings are probably precise to $\pm 5{ }^{\circ} \mathrm{C}$.

The calculated maximum overall error for viscosity values obtained in this study is close to $\pm 15 \%$ relative if $T$ is known within $\pm 10{ }^{\circ} \mathrm{C}$. If $T$ is considered to be constrained within $\pm 5{ }^{\circ} \mathrm{C}$, a precision of $\pm 10 \%$ relative or less is attained for most of the viscosity data reported in Table 3 (viscosity calculated from the settling distance between the marker and the sphere). It is emphasized that the difference of density between glasses and melts, and the error of the determination of the radius of platinum spheres, have not been considered in the precision given above. These errors can be neglected for the determination of the effect of $T$ on the viscosity of a given composition (the same glass cylinder with the same platinum spheres are used).

The precision of viscosity determinations in previous studies is estimated to be $\pm 15 \%$ (Dingwell 1987; White and Montana 1990; Baker and Vaillancourt 1995). Baker and Vaillancourt (1995) performed duplicate experiments for two experimental conditions and the determined viscosities differed by 21 and $5 \%$ relative, which is consistent with an uncertainty of $\pm 15 \%$ relative. However, most of their experiments were performed in piston cylinder apparatus with small capsules $(3 \mathrm{~mm}$ in diameter and 3 to $4 \mathrm{~mm}$ long in some cases, Baker and Vaillancourt 1995; Baker 1996), which increases potential error, especially in the determination of the Faxen correction factor (end effects of the capsule must be taken into account; e.g., Shaw 1963; Baker and Vaillancourt 1995). The marker and the metal spheres were placed in glass powder and the viscosity experiments were conducted directly with this starting material (Dingwell 1987; Baker and Vaillancourt 1995). With this procedure, the initial relative position of spheres and markers is not constrained and both can move during the loading of the capsule in the piston cylinder (glass powder is not a rigid medium). An additional problem in some studies is that glasses were not always prehydrated (water was added to the dry glass for the viscosity experiments of Baker and Vaillancourt 1995; Baker 1996), and heterogeneous distribution of water in the melt at the beginning of the experiment may affect the velocity of the sphere.

Consequently, compared with the technique designed 
by Shaw (1963) and used in this study, it is emphasized that the uncertainties are higher if viscosity is determined from a starting material composed of (dry) glass powder, especially if the settling distances are small (1 to $1.5 \mathrm{~mm}$ in Baker and Vaillancourt 1995). This, together with possible systematic errors resulting from the calculation of the Faxen correction (especially when end effects must be considered), explains the difficulties of combining the viscosities obtained from different data sets (see introduction and Fig. 1). An additional reason for the inconsistent results shown in Figure 1 is the error on the determination of water content, which may be relatively high in some studies. For example, the water contents given by Persikov et al. (1990) for water-saturated Ab melts do not agree with recent water solubility investigations of Behrens (1995) and Romano et al. (1996), and a difference of approximately $1 \mathrm{wt} \% \mathrm{H}_{2} \mathrm{O}$ is observed at $200 \mathrm{MPa}$. All data in Figure 1 can be reconciled if a relative uncertainty of $\pm 15 \%$ on the viscosity determinations is assumed and if the error on the water content of the melt is $\pm 0.7 \mathrm{wt} \% \mathrm{H}_{2} \mathrm{O}$. Thus, uncertainties in the determination of viscosity and melt water content must be reduced if viscosity data for hydrous melts are used to understand or constrain the solubility mechanisms of water in melts.

\section{Effect of silica content and alkalies on the viscosity of hydrous haplogranitic melts}

The experimental results show that, at a constant water content in the melt $\left(2.8 \mathrm{wt} \% \mathrm{H}_{2} \mathrm{O}\right)$, the viscosity (expressed as $\log \eta)$ increases almost linearly with increasing normative $\mathrm{Qz}$ content from $\mathrm{Ab}$ to $\mathrm{Ab}_{50} \mathrm{Qz}_{50}$ (Fig. 2A). At $1200{ }^{\circ} \mathrm{C}$ this increase is approximately $0.65 \log$ units from $\mathrm{Ab}$ to $\mathrm{Ab}_{50} \mathrm{Qz}_{50}$. The increase in viscosity with $\mathrm{Qz}$ content is not surprising, because the same effect is observed in dry melts (e.g., Urbain et al. 1982). The effect of water content and composition on $E_{a}$ is difficult to assess due to the relatively high uncertainties on the $E_{a}$ values (Table 4). $E_{a}$ tends to increase with decreasing water content in $\mathrm{Ab}$ melts (in agreement with most previous investigations, e.g., Dingwell 1987; Persikov et al. 1990; Schulze et al. 1996).

The viscosity curves for two compositions containing approximately the same Qz content, the same water content $\left(2.8 \mathrm{wt} \% \mathrm{H}_{2} \mathrm{O}\right.$ ), but different $\mathrm{Na} / \mathrm{K}$ ratios (AOQ and $\mathrm{Ab}_{75} \mathrm{Qz}_{25}$ ), are similar (Fig. 2B). This suggests that: (1) the effect of replacing $\mathrm{Na}$ by $\mathrm{K}$ on the viscosity of hydrous metaluminous and peraluminous melts is small [in agreement with results obtained for $\mathrm{Ab}$ and Or melts by Dingwell (1987) and White and Montana (1990), respectively]; and (2) a single empirical equation can be formulated to account for both the effects of water and anhydrous composition on the viscosity of haplogranitic melts in the range $10^{3}-10^{5}$ poise.

\section{Calculation of the viscosity of hydrous haplogranitic melts}

As shown in Figure 2B, the equation of Schulze et al. (1996) that was established for $\mathrm{Ab}_{38} \mathrm{Or}_{34} \mathrm{Qz}_{28}$ (AOQ)

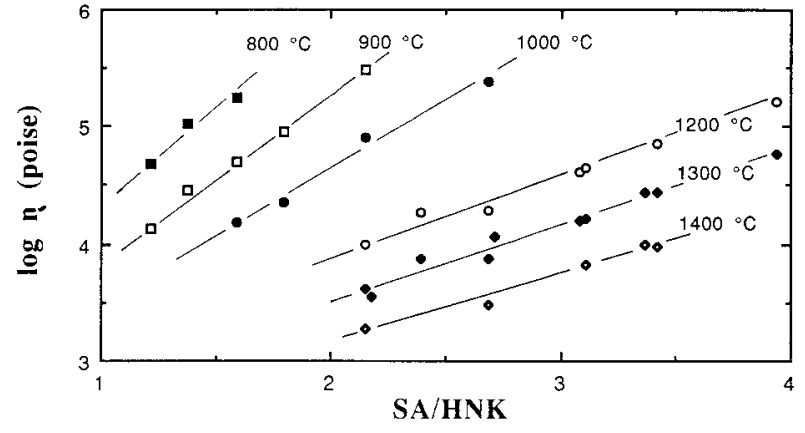

Figure 3. Viscosities of Ab-Qz and AOQ melts as a function of the parameter $\mathrm{SA} / \mathrm{HNK}=(\mathrm{Si}+\mathrm{Al}) /(\mathrm{H}+\mathrm{Na}+\mathrm{K})$ molar. The viscosities for each temperature are represented by different symbols. Symbols represent experimental data or have been extrapolated from experimental data. In the latter case, viscosities have been extrapolated for lower or higher temperatures using the Arrhenius curves for the investigated compositions (from Fig. $2 \mathrm{~A}$ in case of $\mathrm{Ab}-\mathrm{Qz}$ melts). Extrapolation was always $<0.5 \mathrm{log}$ unit from the experimental data.

melts, can be used to predict the viscosity of haplogranitic melts with approximately 30\% normative Qz, but discrepancies are observed if this equation is used to predict the viscosities of hydrous Ab or more Qz-rich melts. Nevertheless, this equation (valid for water contents between 1 and $8 \mathrm{wt} \% \mathrm{H}_{2} \mathrm{O}$ ) can be used to estimate the amount of water that would counterbalance the changing Qz content in a haplogranite melt. Figure $2 \mathrm{~B}$ shows that almost identical viscosity curves are obtained for $\mathrm{Ab}_{50} \mathrm{Qz}_{50}$ melts with 2.8 wt $\% \mathrm{H}_{2} \mathrm{O}$ and AOQ melts with $2.03 \mathrm{wt} \% \mathrm{H}_{2} \mathrm{O}$. The viscosity of $\mathrm{Ab}$ melts with $2.8 \mathrm{wt} \% \mathrm{H}_{2} \mathrm{O}$ is close to that of AOQ melts with $3.63 \mathrm{wt} \% \mathrm{H}_{2} \mathrm{O}$. This suggests that melt viscosity is almost identical for any haplogranitic composition if one $\mathrm{Al}$ charge balanced by $\mathrm{Na}$ or $\mathrm{K}$ is exchanged for one $\mathrm{Si}$ and one $\mathrm{H}(\mathrm{H}$ being incorporated as molecular $\mathrm{H}_{2} \mathrm{O}$ or hydroxyl groups). Thus, the viscosity of hydrous haplogranite melts should be dependent on the molar proportion $(\mathrm{Si}+\mathrm{Al}) /(\mathrm{H}+\mathrm{Na}+\mathrm{K})(-\mathrm{SA} /$ HNK). All viscosity data obtained experimentally by Schulze et al. (1996) for the AOQ composition and in this study have been reported as a function of SA/HNK of the investigated compositions (see values in Table 1) in Figure 3. A linear correlation between $\log \eta$ and SA/ HNK is observed for a given temperature, and the viscosity can be predicted accurately for haplogranitic compositions as a function of SA/HNK and $T$ only. It is emphasized that the compositional factor SA/HNK also accounts for the difference in the effect of water on viscosities of melts with high and low water contents [the effect of water on viscosity is lower in melts with high water contents than in melts with low water contents (e.g., Shaw 1963; Stolper 1982)].

The experimental data have been fitted so that the equation predicting the viscosity has the same form as Equation 3 (this has the advantage that $E_{a}$ can be recal- 
culated for any haplogranitic composition from the SA/ HNK parameter). The best fit equation is:

$$
\log \eta=-1.8+\left[940+5598 \cdot(\mathrm{SA} / \mathrm{HNK})^{0.3774}\right] \cdot 1 / T
$$

where the viscosity is expressed as $\mathrm{d} \cdot \mathrm{Pa} \cdot \mathrm{s}$ and $T$ as kelvin. The pre-exponential factor $\left(\log \eta_{\mathrm{o}}=-1.8\right)$ corresponds to the average value of $\log \eta_{\mathrm{o}}$ determined by Schulze et al. (1996) and in this study. The activation energy $E_{a}$ corresponds to:

$$
E_{a}=\left[940+5598 \cdot(\mathrm{SA} / \mathrm{HNK})^{0.3774}\right] \cdot 2.303 \cdot R
$$

Using Equation 4, viscosity can be predicted with a maximum deviation from the experimental data of $\pm 0.15 \mathrm{log}$ units. The good correlation between the calculated and experimentally determined viscosities is shown in Figure 4A (for AOQ and Ab-Qz compositions) and in Table 3 (for $\mathrm{Ab}-\mathrm{Qz}$ melts).

It is emphasized that Equation 4 is strictly valid only for haplogranitic melts, and no data are available to determine whether this equation can be extended to synthetic peralkaline or strongly peraluminous hydrous compositions. The validity of Equation 4 is established only for the temperature range in which viscosity exhibits an Arrhenian behavior and for water contents between 1 and $8 \mathrm{wt} \% \mathrm{H}_{2} \mathrm{O}$ in AOQ melts and 0.65 and $2.8 \mathrm{wt} \% \mathrm{H}_{2} \mathrm{O}$ in $\mathrm{Ab}$ melts. Considering that pressure has a negligible effect on the viscosity of hydrous melts in the pressure range 250-1000 MPa (Dingwell 1987; Scaillet et al. 1996; Schulze et al. 1996), Equation 4 can be applied at least for this pressure range and also probably down to $100 \mathrm{MPa}$ because Shaw (1963) did not observe a pressure effect on the viscosity of a natural obsidian between 100 and $200 \mathrm{MPa}$. Comparison of the calculated viscosities with those obtained experimentally in previous studies (Ab hydrous melts between 50 and $750 \mathrm{MPa}$ ) shows an overall good agreement (Fig. 4B). The more pronounced scatter of the points in Figure 4B when compared to Figure $4 \mathrm{~A}$ is probably due to large uncertainties in the viscosity data obtained in previous studies. In Figure 4B, only data obtained between 50 and $750 \mathrm{MPa}$ are illustrated. Data obtained at $1500 \mathrm{MPa}$ and above (Dingwell 1987 and Baker 1996 for Ab melts; White and Montana 1990 for Or melts) are not shown because such high pressures may cause a decrease of the viscosity (Dingwell 1987; White and Montana 1990).

The successful prediction of our viscosity data using Equation 4 implies that the exchange of one charge-balanced $\mathrm{Al}$ for one $\mathrm{Si}$ (no depolymerization and no breakage of T-O-T bridges) has the same effect on viscosity as the addition of one $\mathrm{H}$ incorporated as $\mathrm{OH}$ or $\mathrm{H}_{2} \mathrm{O}$ (for proportions of the species in such melts in situ, see e.g., Nowak and Behrens 1995). This may be fortuitous, but may also be interpreted as an observation that is in agreement with the water incorporation model proposed by Kohn et al. (1989), suggesting that water does not depolymerize aluminosilicate liquids (at least in the range 1.5-3.5 wt $\% \mathrm{H}_{2} \mathrm{O}$ ). However, it is emphasized that viscosities calculated from equation 4 for melts with very
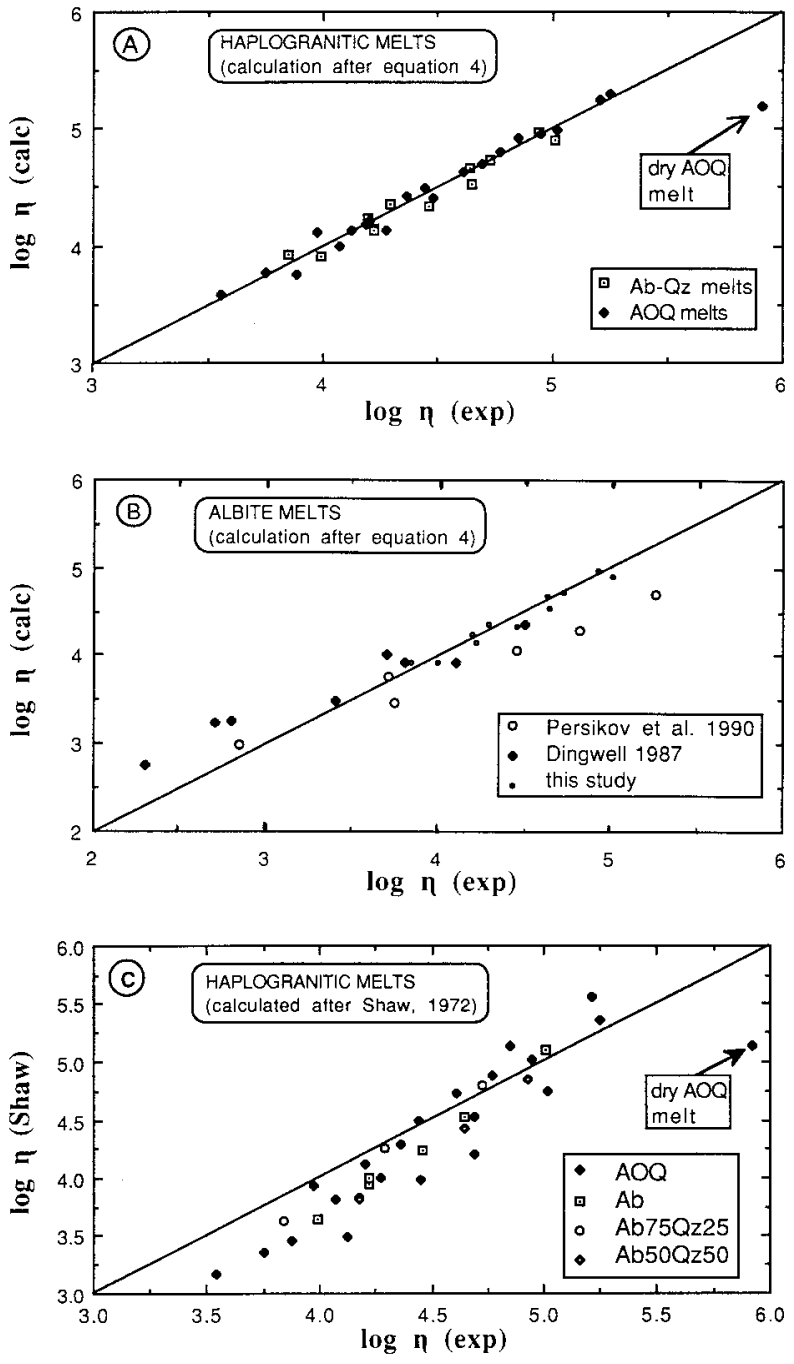

Figure 4. Correlations between measured and calculated viscosities of haplogranitic melts. Points should be located on the lines drawn on Figures $4 \mathrm{~A}$ to $4 \mathrm{C}$ if calculated and experimentally determined viscosities are identical (1:1 line). (A) The experimental data obtained for the dry and hydrous (1 to $8 \mathrm{wt} \%$ $\mathrm{H}_{2} \mathrm{O}$ ) AOQ melts (Schulze et al. 1996) and for hydrous Ab-Qz melts investigated in this study are compared with calculated viscosities using Equation 4 in Figure 4A. All data can be predicted by Equation 4 with a maximum deviation of $\pm 0.15 \mathrm{log}$ units, except for the dry AOQ composition. (B) The experimental data obtained between 50 and $750 \mathrm{MPa}$ for albite melts by Dingwell (1987), Persikov et al. (1990), and in this study are compared with predicted viscosities using Equation 4. (C) The experimental data obtained for the dry and hydrous (1 to $8 \mathrm{wt} \%$ $\mathrm{H}_{2} \mathrm{O}$ ) AOQ melts (Schulze et al. 1996) and for hydrous Ab-Qz melts investigated in this study are compared with calculated viscosities using the model of Shaw (1972).

low water contents are significantly underestimated (Fig. $4 \mathrm{~A})$. The calculated viscosity for dry Ab and AOQ melts at $1400{ }^{\circ} \mathrm{C}$ are $10^{4.41}$ and $10^{5.19}$ poises, whereas experimental data are $10^{5.21}$ and $10^{5.91}$ poises, respectively (Urbain et al. 1982; Schulze et al. 1996). 


\section{Comparison with previous models and implications for the viscosity of natural felsic melts}

The most popular model used to predict the viscosity of natural hydrous silicate melts was proposed by Shaw (1972) and derived from the model of Bottinga and Weill (1972). Recently, several studies have emphasized that the model of Shaw (1972), and therefore also the extension of this model to peraluminous melts proposed by Goto et al. (1997), underestimates the viscosity of waterrich haplogranite melts and overestimates the viscosity of water-poor melts at geologically relevant temperatures (e.g., Baker 1996; Dingwell et al. 1996; Schulze et al. 1996). This is also observed for the Ab-Qz compositions investigated in this study (Fig. 4C). However, in the investigated viscosity range $\left(\log \eta=10^{3.5}-10^{5.5}\right)$, the model of Shaw predicts the viscosity with a maximum error of $\pm 0.5 \log$ units. The differences are expected to be more pronounced for melts with viscosities higher than $10^{5.5}$ poise and lower than $10^{3.5}$ poise (Schulze et al. 1996). For a given experimentally determined viscosity, the predicted viscosity for $A b_{75} \mathrm{Qz}_{25}$ melts is systematically higher than the predicted viscosity for $\mathrm{Ab}$ and $\mathrm{Ab}_{50} \mathrm{Qz}_{50}$ compositions (Fig. 4C). Although these variations are small (0.2 log units), they suggest that the model of Shaw (1972) does not accurately predict the effect of changing $\mathrm{SiO}_{2}$ content in hydrous haplogranitic melts.

The model of Persikov et al. (1990) and Persikov (1991) requires that the proportions of hydroxyl groups and molecular $\mathrm{H}_{2} \mathrm{O}$ be known. This has been determined in situ for the AOQ composition (Nowak and Behrens 1995) and a comparison with the experimental viscosity data (Schulze et al. 1996) obtained for the same composition shows that differences of up to two orders of magnitude between calculated and experimental viscosities are observed at $1300{ }^{\circ} \mathrm{C}$, but better agreement is obtained at $800{ }^{\circ} \mathrm{C}$. A discussion of the limitations of the model of Persikov et al. (1990) is given by Schulze et al. (1996).

Two recent empirical models to predict the viscosity of hydrous natural granitic melts have been published by Baker (1996) and Hess and Dingwell (1996). It is emphasized that these models cannot predict the variations with $\mathrm{SiO}_{2}$ content of the melt observed in this study because both models fail to account for variations in anhydrous compositions. Comparison of the results for $\mathrm{Ab}_{75} \mathrm{Qz}_{25}$ (a composition with a proportion of feldspar and quartz components close to a typical granite) shows that the model of Baker (1996), valid between 700 and 900 ${ }^{\circ} \mathrm{C}$, cannot be extrapolated to higher temperatures. At 980 and $1200{ }^{\circ} \mathrm{C}$, the viscosity of such a melt containing 2.8 wt $\% \mathrm{H}_{2} \mathrm{O}$ would be underestimated by approximately 10 and 100 times, respectively. The model of Hess and Dingwell (1996, Equation 7) predicts adequately the temperature dependence of the viscosity of $\mathrm{Ab}_{75} \mathrm{Qz}_{25}$ (the calculated viscosity is $0.24 \pm 0.02 \log$ units lower than the viscosities obtained experimentally), which can be expected because the data obtained for AOQ compositions by Schulze et al. (1996) were used in the database of Hess and Dingwell (1996). For albite melts with $2.8 \mathrm{wt} \% \mathrm{H}_{2} \mathrm{O}$, the calculated and experimental viscosities are almost identical at $1200{ }^{\circ} \mathrm{C}$. However, it can be noted that the model would fail in predicting adequately the temperature dependence of the viscosity of albite melts. With decreasing temperature from 1200 to $980{ }^{\circ} \mathrm{C}$, an increase in the viscosity of $1.24 \mathrm{log}$ units is predicted, whereas the experimentally determined viscosity increase is $1.02 \mathrm{log}$ units. This deviation is small but shows that the activation energy for viscous flow is significantly dependent on the anhydrous composition of granitic or rhyolitic melts. For such compositions, a change of the anhydrous composition may cause a variation of 20 to $40 \mathrm{~kJ} / \mathrm{mol}$ at high temperatures (900 to $1300{ }^{\circ} \mathrm{C}$, e.g., Holtz et al. 1996). This compositional effect, as well as the non-Arrhenian behavior of viscosity (e.g., Bottinga 1994), must be understood and taken into account if the viscosities of rhyolitic melts are to be predicted with a precision better than that obtained from empirical models. The best empirical model that has been proposed to date is that of Hess and Dingwell (1996) with a standard deviation of $0.46 \log$ units and a validity over a wide viscosity range.

\section{ACKNOWLedgments}

This research was supported by Procope (German-French collaboration programme no. 95023) and the European TMR project "In Situ hydrous melt properties (proposal no. ERBFMRX CT 960063)." The manuscript has been improved by the comments of B. Mysen, M. Pichavant, and B. Scaillet. The manuscript also benefited from reviews by D. Baker, Y. Bottinga, J. Blencoe, and an anonymous reviewer.

\section{REFERENCES CITED}

Bacon, L.R. (1935) Measurement of absolute viscosity by the falling sphere method. Journal of Franklin Institution, 221, 251-273.

Baker, D.R. (1996) Granitic melt viscosities: empirical and configurational entropy models for their calculation. American Mineralogist, 81, 126134.

Baker, D.R. and Vaillancourt, J. (1995) The low viscosities of $\mathrm{F}+\mathrm{H}_{2} \mathrm{O}$ bearing granitic melts and implications for melt extraction and transport. Earth and Planetary Science Letters, 132, 199-211.

Behrens, H. (1995) Determination of water solubilities in high-viscosity melts: an experimental study on $\mathrm{NaAlSi}_{3} \mathrm{O}_{8}$ and $\mathrm{KAlSi}_{3} \mathrm{O}_{8}$ melts. European Journal of Mineralogy, 7, 905-920.

Bottinga, Y. (1994) Non-newtonian rheology of homogeneous silicate melts. Physics and Chemistry of Minerals, 20, 454-459.

Bottinga, Y. and Weill, D.F. (1972) The viscosity of magmatic liquids: a model for calculations. American Journal of Science, 272, 438-475.

Burnham, C.W. (1964) Viscosity of a water-rich pegmatite melt at high pressures. Geological Society of America, Special Papers, 76, 26.

Dingwell, D.B. (1987) Melt viscosities in the system $\mathrm{NaAlSi}_{3} \mathrm{O}_{8}-\mathrm{H}_{2} \mathrm{O}-\mathrm{F}_{2} \mathrm{O}-$ 1. In B.O. Mysen, Ed., Magmatic processes: physicochemical principles, p. 423-433. The Geochemical Society Special Publication no. 1.

Dingwell, D.B. and Mysen, B.O. (1985) Effects of water on the viscosity of albite melt at high pressure: a preliminary investigation. Earth and Planetary Science Letters, 74, 266-274.

Dingwell, D.B., Romano, C., and Hess, K.U. (1996) The effect of water on the viscosity of a haplogranitic melt under P-T-X conditions relevant to silicic volcanism. Contributions to Mineralogy and Petrology, 124, 19-28.

Goto, A., Oshima, H., and Nishida, Y. (1997) Empirical method of calculating the viscosity of peraluminous silicate melts at high temperatures. Journal of Volcanology and Geothermal Research, 76, 319-327.

Hess, K.U. and Dingwell, D.B. (1996) Viscosities of hydrous leucogranitic melts: a non-Arrhenian model. American Mineralogist, 81, 1297-1300.

Holtz, F., Behrens, H., Dingwell, D.B., and Johannes, W. (1995) Water 
solubility in haplogranitic melts. Compositional, pressure and temperature dependence. American Mineralogist, 80, 95-108.

Holtz, F., Scaillet, B., Behrens, H., Schulze, F., and Pichavant, M. (1996) Water contents of felsic melts: application to the rheological properties of granitic magmas. Transactions of the Royal Society of Edinburgh, 87, 57-64.

Kanzaki, M., Kurita, K., Fujii, T., Kato, T., Shimomura, O., and Akimoto, S. (1987). A new technique to measure the viscosity and density of silicate melts at high pressure. In M.H. Manghnani and Y. Syono, Eds., High-pressure research in mineral physics, p. 195-200. American Geophysical Union, Washington, D.C.

Kerr, R.C. and Lister, J.R. (1991) The effects of shape on crystal settling and on the rheology of magmas. Journal of Geology, 99, 457-467.

Kohn, S.C., Dupree, R., and Smith, M.E. (1989) A multinuclear magnetic resonance study of the structure of hydrous albite glasses. Geochimica et Cosmochimica Acta, 53, 2925-2935.

Lejeune, A.M., Holtz, F., Roux, J., and Richet, P. (1994) Rheology of an hydrous andesite: an experimental study at high viscosities. EOS, 75, 724.

Nowak, M. and Behrens, H. (1995) The speciation of water in haplogranitic glasses determined by in situ near-infrared spectroscopy. Geochimica et Cosmochimica Acta, 59, 3445-3450.

Persikov, E.S. (1991) The viscosity of magmatic liquids: experiment, generalized patterns. A model for calculation and prediction. Applications. In L.L. Perchuk and I. Kushiro, Eds., Advances in Physical Geochemistry, p. 1-40. Springer, Heidelberg, New York.

Persikov, E.S., Zharikov, V.A., Bukhtiyarov, P.G., and Polskoy, S.F. (1990) The effects of volatiles on the properties of magmatic melts. European Journal of Mineralogy, 2, 621-642.

Pichavant, M. (1987) Effects of $\mathrm{B}$ and $\mathrm{H}_{2} \mathrm{O}$ on liquidus phase relations in the haplogranite system at 1 kbar. American Mineralogist, 72, 10561070 .

Richet, P., Lejeune, A.M., Holtz, F., and Roux, J. (1996) Water and the viscosity of andesite melts. Chemical Geology, 128, 185-197.
Romano, C., Dingwell, D.B., Behrens, H., and Dolfi, D. (1996) Compositional dependence of $\mathrm{H}_{2} \mathrm{O}$ solubility along the joins $\mathrm{NaAlSi}_{3} \mathrm{O}_{8}$ $\mathrm{KAlSi}_{3} \mathrm{O}_{8}, \mathrm{NaAlSi}_{3} \mathrm{O}_{8}-\mathrm{LiAlSi}_{3} \mathrm{O}_{8}$, and $\mathrm{KAlSi}_{3} \mathrm{O}_{8}-\mathrm{LiAlSi}_{3} \mathrm{O}_{8}$. American Mineralogist, 81, 452-461.

Roux, J. and Lefèvre, A. (1992) A fast-quench device for internally heated pressure vessels. European Journal of Mineralogy, 4, 279-281.

Roux, J., Holtz, F., Lefèvre, A., and Schulze, F. (1994) A reliable hightemperature setup for internally heated pressure vessels: applications to silicate melt studies. American Mineralogist, 79, 1145-1149.

Scaillet, B., Pichavant, M., and Roux, J. (1995) Experimental crystallization of leucogranite magmas. Journal of Petrology, 36, 663-705.

Scaillet, B., Holtz, F., Pichavant, M., and Schmidt, M.O. (1996) The viscosity of Himalayan leucogranites: implications for mechanisms of granitic magma ascent. Journal of Geophysical Research, 101, 2769127699.

Schulze, F., Behrens, H., Holtz, F., Roux, J., and Johannes, W. (1996) The influence of water on the viscosity of a haplogranitic melt. American Mineralogist, 81, 1155-1165.

Shaw, H.R. (1963) Obsidian- $\mathrm{H}_{2} \mathrm{O}$ viscosities at 1000 and 2000 bars in the temperature range 700 to $900{ }^{\circ} \mathrm{C}$. Journal of Geophysical Research, $68,6337-6342$.

(1972) Viscosities of magmatic liquids: an empirical method of prediction. American Journal of Science, 272, 870-893.

Stolper, E. (1982) The speciation of water in silicate melts. Geochimica et Cosmochimica Acta, 46, 2609-2620.

Urbain, G., Bottinga, Y., and Richet, P. (1982) Viscosity of liquid silica, silicates and alumino-silicates. Geochimica et Cosmochimica Acta, 46, 1061-1072.

White, B.S. and Montana, A. (1990) The effect of $\mathrm{H}_{2} \mathrm{O}$ and $\mathrm{CO}_{2}$ on the viscosity of sanidine liquid at high pressures. Journal of Geophysical Research, 95, 15683-15693.

Manuscript Received March 12, 1998

Manuscript accepted August 28, 1998

Paper handled by James G. Blencoe 